insert picture still from Prince's

Kiss Video

It was the writer's intention that this article be illustrated with images of those artists whom she discusses.

Regrettably we were unable to obtain the necessary permission from some of these artists. It was decided therefore to replace all images with instructions for our readers to insert the images for themselves. This action is of course a protest; a protest against censorship in what ever its form. It is not however a criticism of Warner Music NZ Ltd and Sony Music NZ Ltd. Indeed the editors would like to acknowledge the cooperation and efforts of both Warner Music NZ Ltd and Sony Music NZ Ltd in trying to obtain the necessary permission from those artists whom their respective parent company represents.

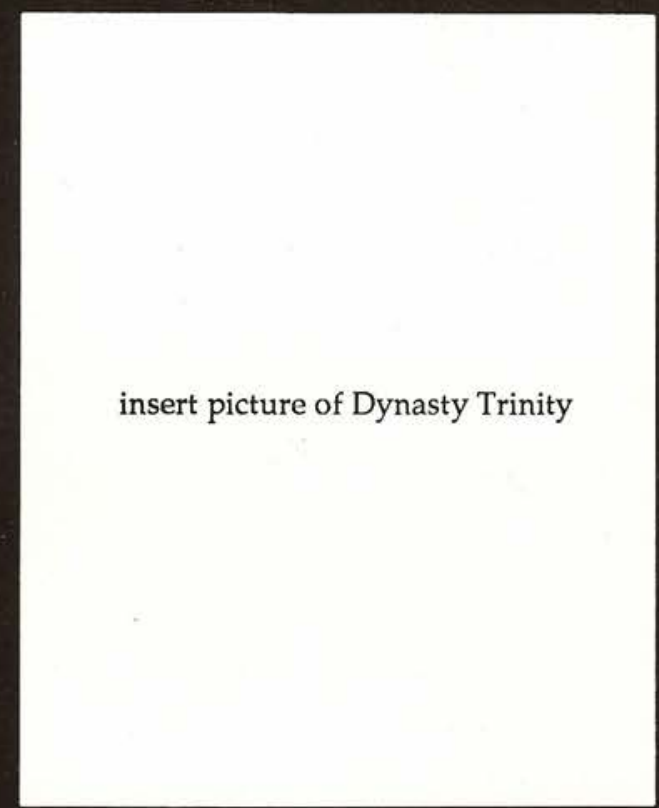




\title{
On Masquerade
}

\author{
A visual-text on sexual stereotypes in the media
}

\section{Lita Barrie}

'The reader may now ask how I define womanliness or where I draw the line between genuine womanliness and the 'masquerade'. My suggestion is not, however, that there is any such difference, whether radical or superficial, they are the same thing Joan Riviere, Womanliness as a Masquerade.1

If language dictates what can be said and thought, 2 then in an era of high-tech communications, media language has the most powerful effects in the determination of our sexual identities. The art of selling sex in today's media relies upon skilful manipulation of fictions which have been passed down through the millenium of patriarchal thought and become embedded in popular memory. By revamping these mythico-religious fictions into sexual signs we unconsciously recognise, the media reinforces the archaic symbolic underpinnings of our presentday libidinal economy.

I want to begin by considering an example of the way feminine sexual identity was represented in a Renaissance economy based on Neo-Platonic symbolism.

Titian's Sacred and Profane Love was executed in 1515 to embody Neo-Platonic ideals of morality in the figures of two Venuses - one clothed and one naked - and originally bore the title Beauty Adorned and Beauty Unadorned.

But the painting became emblematic of the way inherited signs of femininity, acquire different moral evaluations in different periods of history, according to the dominant symbolism of the time.

The allegory of the two Venuses was familiar to a Renaissance audience who inherited the history of two early Greek statues by Praxiteles of a naked and a clothed Venus. The naked Venus was rejected by one island but later glorified by another. During the middle ages the double Venus became a convention for representing nature and grace. In Titian's allegory the adorned Venus is a sign of 'Transient Bliss', who attempts to persuade the Unadorned Venus - 'Eternal Bliss' - to throw away her worldly treasures of gold and jewels. But this reading
Lita Barrie graduated Master of Arts from the University of Victoria, Wellington. Barrie has worked as an eductor and art critic. She has a special interest in contemporary French Feminist Thought and has written for different journals and in a number of catalogues. Barrie now lives in Los Angeles.

1. Joan Riviere, 'Womanliness as a Masquerade' in Formations of Fantasy, Methuen; 1968, p. 38.

2. According to Jacques Lacan's revision of Sigmund Freud's dictum that "anatomy is destiny" it is language which determines the psyche since we are born into language which is structured upon an Oedipal division of sexual identities. 
3. Freidrich Nietzsche, The Gay Science, Vintage Books, 1974; p. 317.

4. Friedrich Nietzsche, Beyond Good and Evil, Penguin; 1973, p. 144.

5. Ibid, p. 145. depended upon the Platonic division between the material world and the world of idealised forms.

The painting was not re-titled Sacred and Profane Love until the 18th-century when its Neo-Platonic frame of reference was lost. Released from its original symbolic subtext, the painting became more problematic to read - as the infamous art-historical debates over what each Venus represents, demonstrate. But the intrigue of the painting is that it exemplifies the 'riddle' femininity poses to patriarchal thought.

Because the 'seen' is privileged over the 'unseen' in masculine imagination, femininity has traditionally been associated with masquerade. If man invented a principle of sexual identity based on his own visible sexual organ, then woman's lack of anything to see has been interpreted as her non-identity. Because woman can only impersonate this non-identity man has given her, femininity has been associated with a mask - as a form of masquerade.

Friedrich Nietzsche provides one of the strongest articulations of the masculine response to feminine adornment as a mask or masquerade beneath which lies some hidden 'unseen' danger. Perturbed by the relation between woman, truth, and adornment he wrote, 'From the very first nothing has been more alien, repugnant, inimical to woman than truth - her great art is the lie, her supreme concern is appearance and beauty'.3

For Nietzsche woman is a lie - the only truth she has is that she is adornment. Even in the sexual act, she is nothing more than an act. As he says 'they "put on something" even when they take off everything. Woman is so artistic'.4

But the underlying sub-text (man's fear of the larynx-with-teeth) was revealed when Nietzsche approached the problem (which later pre-occupied Freud and Lacan) of what woman wants. Because the masculine libido relies upon woman's silence for its stability, the articulation of what woman wants, threatens man. Hence Nietzsche's comment, '. . . already female voices are raised which by holy Aristophanes! make one tremble; there are threatening and medically explicit statements of what woman wants of man'.5 To the 19th-century philosopher this was outrageous. Woman must be re-assigned to a position where she cannot speak for herself - but is spoken for, instead. And that position is the site of the masquerade where woman silently mirrors the claims man has imprinted upon her. This non-identity must be worn as a mask which is never removed in case the flaw in man's fiction was exposed by the suggestion of a 'different' feminine subjectivity, which escapes masculine logic.

Interestingly, it was a woman who provided the first psycho-analytic explanation of feminine masquerade as a defence woman used in a masculine regime. In 1929 Joan 
Riviere developed her argument from a case study of an intellectual woman who, as a defence against male reprisal for exhibiting her intellectualism in public speaking engagements, sought male re-assurance by 'means of flirting and coquetting in a more or less veiled manner'.6 Riviere applied Freud's idea of Oedipal rivalry to argue that in the act of public speaking, this woman symbolically exhibited herself in possession of the father's penis and, having castrated him, must placate his anger by masquerading femininity to father substitutes - in effect 'disguising herself as merely a castrated woman'.7

Riviere emphasised the enigma femininity represents to man, arguing that womanliness is a mask 'behind which man suspects some hidden danger'.8 But this enigma is man's perspective, his image of woman, so that Riviere was trapped in a contradictory position in her attempt to unravel it. Ironically, her own life became the re-enactment of the case study from which her argument was developed. As a punishment for attempting to unravel a 'riddle' man invented, Freud diagnosed her as an hysteric. But as Stephen Heath commented, 'hysteria is what?' Failed masquerade. The hysteric will not play the game, misses her identity as woman. ${ }^{9}$ As he says, 'Riviere is admirable and disturbing and so disturbed'.10 As a woman who dared to analyze her own identity, Riviere failed to masquerade 'properly' according to the law-of-father-Freud, her analyst-teacher.

After all, man invented the conception of woman as the 'dark continent' to ensure that only he can shed light on his mystery. Man has the ultimate sanction that his word is law, because he has transcended himself into the 'voice of God'. Disembodying himself to speak from this lofty position he then has the authority to impregnate her body with his word. Thus her identity becomes his 'immaculate conception'.

Her fate is written - $\mathrm{a}$ fate which sentences her to a death of silence. And since it has been written' in a language which only he can pronounce with the authority of the universe he created behind him, he can adapt his conception of her to suit the economy of the time.

The mass-media construction of Lady Di as a present-day Madonna with child relies on thoroughly coded images that manipulate memories of biblical icons and Virgin Queens. Of course, Diana was invented to ensure the maintenance of a patriarchal regime at a time when women had gone further toward articulating what they want than Nietzsche could have imagined in his worst nightmares.

The young Diana had a much publicised virginity and her major aspiration was to bear children. If man has ensured that woman's maternal functions take precedence over her own specific (erotic) desires, then Di served as a sign of the re-inscription of woman as a glamourised breeding mare with a phallic economy.
6. Joan Riviere, 'Womanliness as a Masquerade' in Formations of Fantasy, Methuen, 1986; p. 36.

7. Ibid, p. 38.

8. Ibid, p. 43.

9. Stephen Heath: Joan Riviere and the Masquerade' in Formations of Fantasy, Methuen, 1986; p. 51.

10. Ibid. 
She neither looked nor talked back - but, instead, carefully kept her eyes turned downward maintaining her silence - so that she never recalled the danger of what might lie beneath feminine masquerade. Diana showed no desire to walk in her own forest. Instead, she followed the path of 'proper' behaviour which eventually led her down the aisle to marry a Prince - just as she had been told in man's fictions.

Because Di was invented to ensure that other little girls could learn to masquerade 'properly', her masquerade became high extravaganza on the day she assumed the royal veil to travel in a medieval coach to the altar where she exchanged the nameof-the-Father for the name-of-the-Prince, in a mass-media spectacle with a global following of millions.

On the night of her deflowering crowds hailed outside her royal bedroom window. The next morning BBC reporters speculated on the date for a royal heir. And within a year, Diana delivered a new prince, named according to the law-of-the-Father as a potential King. Diana became a new fertility symbol, revamped as a sign that maternity had gained a new prestige. She served a burgeoning fashion industry and sanctified the place of royalty once again in a depressed English economy. Royal Britannia was not sinking After all - it had a new Virgin Queen, a white Madonna, an icon for its postage stamps.

Meanwhile, on the other side of the Atlantic, television's Dynasty revamps biblical fictions, appropriating the original protaganists as new signs of sexual identity within a monetarist economy. Blake becomes a sign of the law-of-the-Father, while his angelic wife is a crystal (Krystle) through which he sees a reflection of himself as a benevolent patriarch of a corporate dynasty. As a revamped Virgin Queen, Krystle embodies patriarchal ideals of feminine goodness in opposition to all that is evil embodied by his de-throned wife. Alexis, a revamped Mary Magdalene.

This ruthless siren is a sign of the matriarch-turned-mogul-woman, who outplays the corporate patriarch at his own game by following pagan rules. In her blood wedding she became the widow spider, changing patrimonial names to acquire an even bigger corporate dynasty than this. She takes younger lovers as her consorts, and her heirs must choose between the profane love of the mother and the sacred law-of-the-Father.

But in this re-play of biblical fiction, the protaganists no longer elicit a single 'proper' reading. Krystle might be a sign of the perfect feminine masquerade, but to many younger women her 'proper' behaviour is boring. As the crystal that mirrors man's absurd privilege, her masquerade reflects the subordination of woman's desires to man's - which simply does not inspire 'girls who just want to have fun' (Cyndi Lauper). 
Alexis is a more complex sign of feminine masquerade taken to excess. By foregrounding the masquerade, she suggests the 'unseen' danger Nietzsche feared lay beneath the feminine mask. As Mary-Ann Doane comments 'what is not understandable within the given terms is why a woman might flaunt her femininity, produce herself in excess of femininity, in other words foreground the masquerade'.11 By flaunting femininity, Alexis suggests that it is a mask, which is not only worn but can also be removed.

Freud traced the experience of evil to the formation of the castration neurosis, when the boy first sees the mother's unveiled body. The femme fatale who produces femininity in excess, by exaggerating the accoutrements of femininity as accoutrements, is regarded as evil by men because she arouses masculine desire while simultaneously recalling the castration threat that woman's body symbolises.

Alexis is a supreme symbol of the femme fatale who (like Marlene Dietrich and Joan Crawford), can suggest that even her own body is a disguise. By exaggerating her poses as poses and her pouting as pouting, she recalls Nietzsche's comment that 'they "put on something" even when they take off everything'. By reflecting this paradox, the femme fatale acts as a mirror for what man both wants to see and does not want to see in himself. The woman who masquerades-in-excess becornes the embodiment of evil and desire (agony and ecstasy). As Michele Montrelay comments 'woman is not accused of thinking or committing this evil, but of incarnating it. It is this evil which scandalises whenever woman 'plays out' her sex in order to evade the word and the law'.12

Not only does Alexis's masquerade-in-excess recall the ever-present castration threat woman's body symbolises, but her aura of danger is accentuated by her succession of younger consorts, recalling pagan myths of Fertility Queens who annually took son-lovers who died at the end of each season. These mythological fictions are interwoven into the sign of the corporate mogul woman, to suggest the danger of present-day female power by evoking memories of the ancient matriarch. (Angela in Falcon Crest also symbolises the danger of the matriarch-turned-mogul woman, and Maxine in Gloss is a similar symbol of dangerous female power in a monetarist economy).

In today's libidinal economy women are beginning to claim both money and power so that the super-bitch has become the object of desire and fear.

Interviewed on her recent best-seller, Ambition - on the plight of corporate bitches - Julie Burchill responded to the question of how she herself became a super-bitch by answering 'a combination of nature, nurture and Nietzsche'. As a super-bitch,
11. Mary Ann Doane, 'Film and the Masquerade: Theorising the Female Spectator in Screen, September/October 1982; p. 81.

12. Michele Montrelay, 'Inquiry into Femininity' in French Feminist Thought A Reader ed. Toril Moi, Basil Blackwell, 1987; p. 237. 
insert picture of Botticelli's

Madonna and Christ Child

insert picture of Michael Jackson from the cover of his Bad album

insert picture of L.L. Cool. J. from the cover of his Bad album

insert picture of Princess of

Wales and Prince Harold 
insert picture of Jackie and Joan Collins, sitting together in back of limousine

$\bullet$

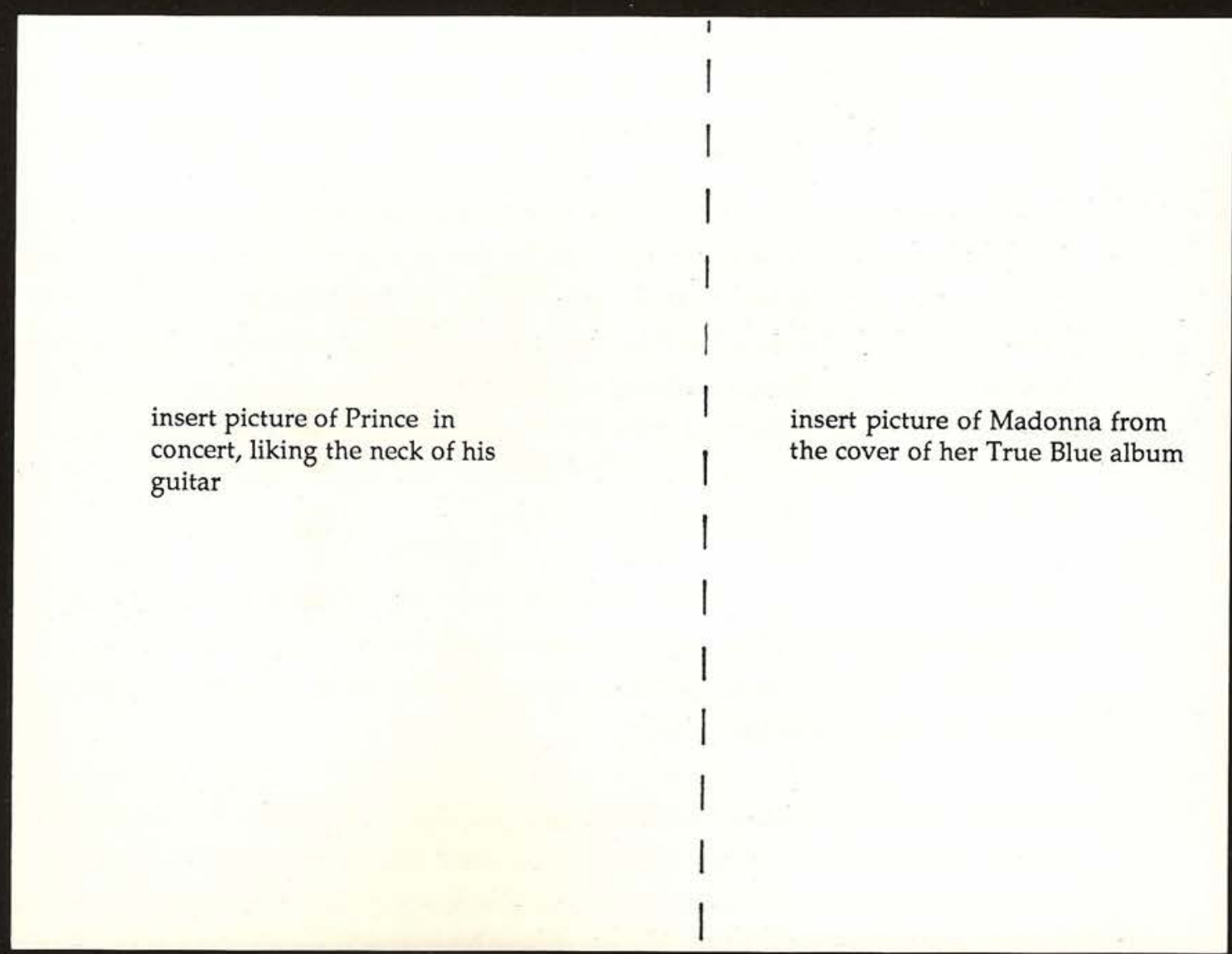


Alexis embodies the male fantasy of dangerous femininity - but the question of what she means to herself, remains.

The character of Alexis is incorporated into the media invention of Joan Collins. Off-screen she acts-out a further permutation of the male fantasy of the femme fatale through her re-emergence to fame and fortune in her sister's screenplay, The Stud. But despite the female authorship the script merely rehearsed the masculine perspective of fictions passed down through time immemorial.

Today, the sisters of glitz are 'Queens of the Road' - twin Venuses of profane love travelling the highway. But they follow the path of masculine logic where woman can only say what man has invented. Since to say what she wants, women would have to re-invent a different logic in which improprieties could be suggested to disrupt man's repressive logic.

Madonna, the rock singer, also acts-out the masquerade-in-excess, but to parody the logic underpinning man's conception of woman - rather than to reflect the paradox of 'unseen' danger the femme fatale symbolises. By mixing-up the logic of the virgin and the whore and sacred and profane love, in a fusion of religion and sex, she has earned her name as the 'Immaculate Mis-conception'. Madonna makes the 'riddle' woman represents to man ridiculous by blatantly manipulating sacred images with profane lyrics and dance movements, to confuse the logic of morality and immorality, repression and lust in her performance of songs such as Like a Virgin.

In Papa don't Preach she parodies the sanctimoniousness of the sacred law-of-theFather and in Like a Prayer she goes furtherest in suggesting how the Church is built around the repressed erotic connotations of the virgin's body - which is linked to rape. In the video for Who's that girl Madonna parodies the use of woman's body for male voyeurism by playing a cabaret performer in a peep show - recalling Marlene Dietrich's performance in The Blue Angel. With camera cuts to spot the sociologist in the audience who is scribbling notes, and a young boy whom she befriends, she turns the spectacle into a joke.

Madonna has sometimes been described as a 'new feminist' who proves that feminism can be fun. As an anti-dote to puritanic forms of 70 s po-faced feminism it is refreshing to see a revamped Monroe gone down market in floozy style, who enjoys the masquerade as a game.

But her parody of feminine masquerade is just that - a parody - in which she is finally reduced to enjoying a joke upon women that men invented. Perhaps the question of an alternative image of woman also involves an alternative to the image. Woman's relation to the scopic regime differs from man's, because she is positioned as passive object of the actively male structure of 'the look'. Madonna offers the 
image of the female body man has coded for his own pleasure - rather than suggesting it is she who inhabits her own body. Rather than the 'disruptive excess', Luce Irigaray suggests as a way of subverting the masquerade 'to re-discover a possible space for the feminine imagination' 13 she runs the risk of being reduced to the masquerade woman is traditionally assigned.

To re-write the meanings of woman's body, pre-supposes a work on language. It is no accident that since the publication of Riviere's article in 1929 a number of feminist theorists have addressed the problem of woman's entrapment in the masquerade. But this has also coincided with the development of cinema - a multimillion dollar industry that relies on woman's position as silent icon for the pleasure of the male spectator.

Women's sexual realities will only change through a disruption of the repressive symbolic structures that dictate the way women are seen and spoken of. The new mobile woman of the future who can escape the fixed identity man invented, will only emerge after woman's body has been recoded in terms of specifically feminine desires which are beyond masculine logic. For this reason French feminist philosophers advocate a feminine writing or écriture that owes a debt to the corporeality of the feminine body - which is related to jouissance (a specifically feminine bodily, sexual pleasure which fragments notions of fixed identity). ${ }^{14}$ Images that suggest a specifically feminine corporeality are potentially subversive to masculine logic - but because woman is fictionalised as nothing more than an image, this is a problematic undertaking. Black soul, and rhythm and blues singers seem to be closer to suggesting such feminine corporeality through their lyrics and movements.

To rewrite the meaning of feminine masquerade seems then, to require more than foregrounding its artifice. Because the masquerade is a male fantasy, it can only be subverted through the suggestion of a corporeality which is linked to a 'different' feminine imagination ... which, perhaps, Mae West went furtherest to suggest with linguistic improprieties which contradicted her image in the masquerade.

In a libidinal economy based on the opposition man/woman, the counterpart to feminine masquerade is masculine display. Man's masculinity relies upon an imaginary relation to the symbolic phallus he, himself, can never possess. As Lemoine Luccione comments, 'Display just like the masquerade thus betrays a flaw: no one has the phallus'.15 The accoutrements of masculine display have traditionally been chosen for their phallic suggestions. Like the masquerade, display is a re-enactment of power relations. In rock music, the charade of phallic power has some of the most vivid effects in reinforcing the symbolic identifications which determine sexual realities.
13. Luce Irigaray, This Sex which is not One, Cornell University Press, 1985; p. 76.

14. 'Jouissance' is the leitmotif of French feminism. The possibility of disrupting the symbolic edifice which defines woman in relation to man depends upon the articulation of a feminine sexual 'difference' which is repressed by language. Since, as Luce Irigaray says, "feminine pleasure signifies the greatest threat of all to masculine discourse, reprewents its most irreducible "exteriority" or "exterritoriality". This sex which Is Not One, op. cit., p. 157.

15. Eugene Lemione Luccioni, cited in Stephen Heath, op. cit., p. 56. 
Because the act of looking is a masculine position, images of masculine display serve man's narcissism. But the effects of masculine display become more complex when combined with masquerade - for example, when Michael Jackson became Bad.

Jackson's masquerade mixes-up different social codes in a racial/class masquerade in which Jackson as the middle-class Hollywood inspired black attempts to re-fashion himself in the mask of a ghetto black. 'Bad' is black jargon for affirmation and used in hip hop music. Perhaps to recover the black audience from whom he was becoming increasingly alienated as his success in the white media economy grew, Jackson borrows signs used by 'bad' ghetto musicians, like L.L. Cool.

The record cover for Jackson's Bad album is a masquerade of the hard, tough, phallicness of the L.L. Cool album, transformed into a Hollywood version of glamourised black leather and chains. Cool is part of a black resistance which risks real danger on stage (provoking gun shooting) which marks the anti-thesis of the plastic-fantastic conventions Jackson attempts to conceal by re-inventing himself as Bad.

Jackson's multi-million dollar Bad video ironically became the white fantasy of ghetto black resistance. Produced by Martin Scorsese in classic white Hollywood tradition - not dissimilar to his earlier Beat It video - it is based on the riot scenes in West Side Story (the prototype of this genre) and Saturday Night Fever.

The narrative is based on the story of Edwin Perry, a Harlem black who gained a scholarship to the prestigious Exeter academy. To the black community he became a symbol of upward mobility, so that when he was found shot after attempting to rob a plain clothes policeman a widely publicised controversy arose which disclosed Perry's secret double-life as a gang member during his returns to Harlem in the school holidays. In the Bad video Jackson masquerades as Perry returning to Harlem where members of his gang ask him to prove he is still 'bad', by joining a hunt in the Harlem subway. But when he is confronted by an Hispanic victim he warns him to run. The other gang members rebuke him saying, 'you ain't bad you ain't nothing' and Jackson must re-establish himself by being reborn bad. He re-appears in black leather and chains - accoutrements of phallic display - in a highly-stylised hip thrusting dance sequence.

Jackson's masquerade is a bizarre conflation of on-and-off screen biography because the Bad video was made as a come-back after years off-screen while he had extensive plastic surgery to replicate the feminine features of his mother-fantasy, Diana Ross.

Jackson's phallic display in a class masquerade becomes more complex because it conceals a mother-identification. Jackson becomes a sign of the 'hysteric phallic', as 
Richard Dyer describes men who display masculinity in excess because it is in doubt. Jackson's attempt to over-produce masculinity suggests that he is concealing a psychological crisis. His phallic display is thus confused with a convoluted masquerade which disguises an identity-crisis, related to both class origins and sexual identity. Although his use of artifice suggests the extent to which masculinity (like femininity) is a cultural invention, Jackson's performances are still an attempt to project the fiction of fixed, stable, sexual identity.

Prince, on the other hand, suspends the fiction of truth and exposes the simulation involved in sexual identity. The high-camp trollop of rock and roll, riddles the fiction of a fixed, sexual identity by mixing-up the logic of masculine display and feminine masquerade, knowingly. 16

At one time he might carry masculine display to sleazy excess with phallic substitutes like his motorbike or guitar. By over-producing the narcissism inherent in masculine display he confuses homo-, hetero-, and auto-eroticism. The semantic concern in these images is to be excessively unsubtle. But he also masquerades effeminacy, adopting the mask of the luxurious feminine in heavy make-up, rufflettes, lace and velvet - in images which draw on the same iconography as Titian's Sacred and Profane Love. By playing-out what Nietzsche called woman's 'genius for finery', he contradicts the masculine identity suggested by the phallic displays.

But he also twists rock and roll messianic conventions, by acting-out the role of the sacred Eastern Prince, adopting a caftan and cross costume. By exaggerating religiosity in songs like The Cross, he parodies sacred belief until he reaches blasphemy.

Prince is a highly complex Sign of the Times when sexual realities are in a process of shifting from the fixed male/female opposition, to an awareness of sexuality as a cultural construction, which allows more play, reversibility, and exchangeability. In Prince's Kiss video, he riddles notions of fixed, sexual identity by fracturing himself into two bi-sexual personas. He appears as the singer-dancer, performing to the music of a woman guitarist who becomes the straight man or full guy. Prince actsout a male bi-sexual persona in a mid-drift who dances with a veiled woman in sunglasses who, iconographically, functions as his female bi-sexual persona. This splintering of stable, sexual identity is suggested by fleeting insets of a veiled woman who sings in a deep male voice - in contrast to Prince's high, feminine singing voice.

The lyrics emphasise that a game is being played out with sexual identities. Prince sings: 'there is no particular sign I'm compatible with', using his hands to suggest Venus and Mars symbols. The choreography incorporates Kundalini movements
16. Prince's private life relations with women which would appear to be very domineering cannot be confused with his semantic concerns in images and songs. 
over the crutch to suggest bi-sexual Tantric sexuality. He sings 'you don't have to watch Dynasty to have an attitude' - emphasising the fiction involved in the portrayal of polarised male-female sexual identities in the television allegory.

Fleeting insets overlaying double images of Prince's face against the bi-sexual couple, occur very quickly to have a subliminal effect. The video operates as spectacle in contrast to the conventional linear narrative effects in Jackson's Bad video, to elicit more unconscious sexual identifications. The digital signs in the video further emphasise this splintering and fracturing of so-called stable sexual identity. In the era of AIDS it is intriguing that Prince exaggerates sexual performance until it is suspended as a self-referential act - beyond actual references - suggesting a simulacra of free floating, exchangeable sexual identities.

But Prince takes 'gender-fuck' to its furtherest excess on the cover of his Love-Sexy album. The image conflates sacred and profane feminine masquerade. If Nietzsche insisted that women "put on something" even when they take off everything', then Prince shows that the male body can also be used as a disguise.

Posed as a little Thumberlina who arouses an orchid stamen, he confuses the symbolic underpinnings of the image. By concealing his genitals he makes the image sexually ambiguous, because the supine pose with the hand over the nipple is a commutation of a female pin-up. The aroused orchid stamen then becomes a confusing index for reading the image: does it represent man's imaginary relation to the symbol of the phallus or woman's arousal of a piece of male anatomy?

The image plays upon contradictions to break the viewer's habitual sexual identifications - because it is uncertain whether Prince is offering a narcissistic image for the male viewer or a fetish for the female voyeur. Of course, it is a far less complex undertaking to subvert sexual identify from the position of male privilege than from one of female subordination. Unsurprisingly, Prince can image himself to confuse sexual identifications in a way that it is probably not yet possible for women to do with images alone (since a contradictory text seems to be required to subvert feminine masquerade). The Love-Sexy image is a sign of riddled sacred and profane love in our own time when it has at least become possible to play a semiotic game of pederastic femininity. Which is just a way of saying: you can be want you want to be...

Note: My special thanks to Lawrence McDonald who provided valued stimuli in discussions preceding the writing of this essay. 
insert picture of Prince in Messianic costume

insert picture of Titian's Sacred and profane love

insert picture of Prince from his Love-sexy album 